https://doi.org/10.24101/logos.2018.36

Gauta 20180323

KASTYTIS RUDOKAS

Kauno technologijos universitetas, Lietuva

Kaunas University of Technology, Lithuania

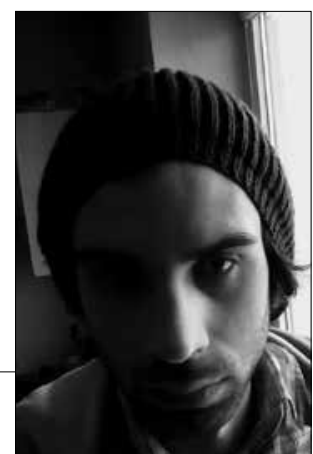

\title{
KAI KURIE METAFIZINIAI ARCHITEKTÜROS PAVELDO ASPEKTAI
}

\author{
Some Metaphysical Aspects of Architectural Heritage
}

\section{SUMMARY}

The paper seeks to expand the limits of meta-theory of cultural heritage by shedding light on discussion about meaning and purpose of phenomenon of heritage itself. Meta-theoretic approach delves deeper into perception of tangible architectural heritage of urban areas and claims that the matter of separate building or the complex of buildings should not be regarded as the decisive feature in evaluation of its authenticity. Therefore the paper implies that authenticity is to be found in causality of space-time continuum that stretches far beyond the physical object.

\section{SANTRAUKA}

Straipsnis skirtas Lietuvoje neegzistuojančiai, arba egzistuojančiai tik fragmentiškai, kultūros paveldo metateorijos problematikai. Pagrindiniai metateorijos keliami klausimai susiję su paveldo esmės ir reikšmės problematika. Šioje diskusijoje pasirenkama svarstyti autentiškumo kaip substancijos konfigūracijas išeinant iš materialaus paveldo objekto suvokimo rẻmų, kai tyrimo objektas yra architektūros ir urbanistikos paveldas miesto vietovèse.

\section{IVADAS}

Darbas yra skirtas išsamiau pažvelgti i architektūros paveldo supratimo problematiką ir tokio paveldo prasmès apskritai klausimą. Lyg ir nekyla klausimas, jog istorinių artefaktų išsaugoji- mas leidžia užmegzti savotišką ryši su praeitimi ir taip suvokti, igyti identitetą. Tačiau vargu ar materialaus artefakto išsaugojimas savaime ši ryši kurianti identitetą užmezga. Kitas problemos 
aspektas - tiesmukas paveldo objekto traktavimas, kai objektą bandoma pririšti prie kokios nors subjektyviai objektyvizuotos prasmès, ką ir parodo šiuolaikinis Kauno modernizmo įženklinimas í "optimizmo architektūros" rūbą. Galima ginčytis, tačiau optimizmo savybę galima priskirti tiek pat kiekvienam reiškiniui, kiek jam galima priskirti ir pesimizmo ar realizmo savybę.

Todèl šio straipsnio tikslas yra pažvelgti $i$ architektūros paveldo prasmę per metafizikos kaip prieigos prizmę, principine pozicija prisiimant požiūri, jog architektūros paveldas ir jo raida istorijos kontinuume supratimo aspektu yra savotiškas būdas pažvelgti i̇ mitinès, diskursyviajją pagrindžianti̇, realybės pasauli. Šis tyrimas paveldą vertina kaip begalinès aibės monadologini turini, $\mathrm{ku}-$ ris yra savaime integralus.
Darbo metodas remiasi keliomis mokslinemis teorinėmis koncepcijomis. Visu pirma Leinizo ir Spinozos monadologinėmis įžvalgomis ir ju aiškinimais XXI a. metafizikoje. Daroma prielaida, jog paveldas veikia kaip monada - yra saviintegralus ir šiuo požiūriu nehierarchiškas. Koncepcija sutvirtinama $\mathrm{Ch}$. Alexanderio ižvalgomis apie „šventą objektą" ir jo veikimą.

Begalybės konceptas perimamas iš klasikinio teizmo interpretacijos matematikos tyrimu lauke. Remiantis Erico Steinharto interpretacija, begalybės ar begalinès aibès supratimas grindžiamas inicijuojančio objekto, tęsiančio objekto ir baigiamojo objekto pakopomis ${ }^{1}$, todèl toks aiškinimo pobūdis taikomas ir kalbant apie architektūros pavelda, kuri pagrindžianti substancija naratyviniu aspektu yra begalinè.

\section{VIENIS IR BEGALINE் AIBE். MIESTAS KAIP MONADOLOGINIS TAPSMAS}

S. G. Venkataramani neilgame traktate Nuostabus susiliejimas: mokslas, metafizika ir religija vaizdžiai nurodo šių skirtingu karalijų bendrą prigimti, vieną jas visas valdanti principa, kuri jis pasirinktinai leidžia vadinti realybe arba protu, arba Dievu - kaip pamatine kuriančia substancija $^{2}$. Veikalo įdomumas yra tas, jog net ir labiausiai praktinius žmogaus veiklos kaip objektyvistinès realybės aspektus autorius susieja su minèta pamatine kuriančia jèga, pastarają atskleisdamas kaip santyki tarp visiškų skirtybių. Vakaru pasaulio filosofija iki pat postmodernybès isigalëjimo mégino atskleisti, kas yra visu daiktu ir reiškiniu pamatas ir kokia yra absoliuti egzistencijos priežastis.
Eidami Venkataramani pramintu keliu, mes pabandysime giliau pažvelgti i architektūros paveldo metafizinès tikrovès, jei tokia egzistuoja, ypatumus per absoliutaus laiko ir erdvės principus. Iki šiol buvo ịprasta architektūros paveldą suvokti kaip objektyvu ir pakankamai statišką reiškinį, kuriam bandoma suteikti galybè pridètiniu, vadybinių, aktualizuojančiu atributu, ir laikyti ji ",dinamišku" dèl indukuotu verčių sistemos. Antai plačiai nuskambejjęs kino teatro "Lietuva" paveldosauginis protestas 2005 ir 2009 m. iš esmès rèmèsi vakarietiška aktualizacijos prielaida, jog paveldas yra vertingas ne dèl architektūros, istorinio konteksto ar itakos sociumui, 
bet atvirkščiai - dèl sociumo pasiryžimo paprastą namą pakišti po paveldo skèčiu dèl kokių nors, išimtinai subjektyviai i̇diegiamų verčių. Tad architektūra, ypač istorinè, tampa ne žinių šaltiniu, suteikusiu galimybę praskleisti šydą ir leidžiančiu pažvelgti i miestą kaip save kurianti organizmą bet tuščiu konteineriu, kuriam būtina suteikti prasmę.

Tokia visuomenès būklè, kalbant apie Lietuva, nors galioja ne vien jai, yra aiškinama negebejjimu sukurti paveldą nè viename iš priežastinio šio egzistavimo lygmenų: (1) miestuose kuriamos prastos naujos urbanistinès ir architektūrinès erdvès dèl beatodairiško siekio pasivyti ir susitapatinti su vakarietišku kultūros turiniu bei (2) materialus požiūris ị kultūrinį turinį atsiranda dèl didelio laiko tèkmès pagreičio, kurio lèksme nei individas, nei visuomené negali kontempliatyviai abstrahuoti paveldo objekto i principinius valstybès ir tautos siekius, idealus ir jos egzistenciją pagrindžiančią substanciją.

Todèl statiškas miesto paveldo vertinimas yra žalingas, nes materialaus objekto perdètas saugojimas (turima omeny tik materialiosios substancijos restauracinès / rekonstrukcinès praktikos oficialiojoje paveldosaugos sistemoje bei pseudo iniciatyvos iš apačios visuomenejje) neužtikrina nematerialiosios, materialujij dèmenị valdančios substancijos išsaugojimo. Priešingai, rodos, išsaugoję vieną ar kitą istorinę materialiają substanciją mieste, mes neretai iš tikruju prarandame dali paveldo fenomenui kaip gilesniam, mitologiniam miesto raidos supratimo komponentui būdingų kokybinių savybių.

1984 m. Aldo Rossi išleido knygą Miesto architektūra, kurioje įtaigiai apibrè- žè kaitos aspekto reikšmę kalbant apie urbanistini paveldą. Anot autoriaus, miesto tapatumas atsiskleidžia ne pavieniuose pastatuose ir net ne santykyje tarp skirtingu pastatu ar skirtingu epochu (nors santykis čia autoriui yra svarbesnis nei vieno pavienio pastato fizinis autentiškumas), bet veikiau savotiškame vyksme, kai architektūra "užduoda“ naujas funkcijas miesto potencialiai ateičiai. Diachorinio samprotavimo būdu ịvertinant Rossi mintis, galime reziumuoti, jog tam tikra prasme Rossi ir antikinis stadionas, ir neoklasikinis operos pastatas bus surišti priežasties ir pasekmès dėsniu, nes net ju architektūrinè kalba neabejotinai bus kilusi iš vieno genotipo.

Todèl miesto architektūrinio paveldo esmè glūdi naratyve, besiskleidžiančiame tarp mitinès (viską kuriančios statiškos plotmès, Dievo, aukščiausiojo proto, logoso ar pan.) ir diskursyviosios realybiu (laikino tam tikros kultūros supratimo apie supančią aplinką) $)^{3}$.

Turbūt išsamiausią modeli siekiant suvokti miestišką architektūros paveldo prigimtị ir jo paskirti pateikia vienas iškiliausių visu laikų architektūros teorijos autoriu Christoferis Alexanderis ${ }^{4}$, kartu su kolegomis perkeltine prasme aprašydamas miestišką architektūros pavelda, teigia, jog kiekviename mieste, mažesnejje ar didesnëje gyvenvietëje yra „šventas objektas", kuris bendruomenès nariams dèl savo sakraliu atributu yra svarbesnis nei visi kiti. Čia reikia pažymèti, jog Alexanderis, kalbėdamas apie „šventą objektą", turi omenyje nebūtinai architektūros ar urbanistikos artefaktą, bet apskritai bet kurią vietovę ar objekta, turintị tą metafizinę „„šventumo" savybę. Todèl „švento objekto“ terminą mes ga- 
lime laikyti savotiška inicijuojančia alegorija - tapatybę lemiančia nematerialia substancija, kuri transcenduoja į realybę ir pagrindžia miesto ar vietovès fizinę egzistenciją.

Alexanderis siūlo šį „šventą objektą“ ivilkti i jaukią aplinką (angl. versijoje nested percinct), kur ta aplinka atspindètụ to objekto esmę. Tad klaidinga būtụ manyti, jog paveldosaugoje pasirenkami aukštingumo, "raudonosios linijos", stogu linijos ar kiti aspektai atspindi Alexanderio modulio principą. Ne formalus pakartojimas, bet idejjinis tęstinumas, jei kartais ir reikia, kaip teigia tradicijos ir metatradicijos sandarą nagrinejjantis Tomas Kačerauskas ${ }^{5}$, turi būti papildomas visiškai revoliucingais vizualiniais sprendiniais.

İdomu tai, kad pavyzdžiui, Vilniuje tokia šventa vieta galètų būti Šventaragio slènis. İdomu ir tai, kad pilis statoma, kaip ir daugelyje Lietuvos vietoviu, ant piliakalnio - gamtos ir technikos darnios sajungos, kur natūra ir kultūra veikia per savotišką vienovę. Šiuo aspektu Vincas Vyčinas, kalbėdamas apie mitologinị lietuvišką identitetą pabrèžia, kad mitinis lietuvis (kaip transcendentinis logos, išlikęs laisvụjų valstiečių identitete) remiasi esminiu principu, jog iš gamtos imama tik tiek, kiek reikia. Būtent tai, anot Vyčino, užtikrina lietuviškos egzistencijos tęstinumą ir jis pagrindžia bei laiduoja santyki su dievais ${ }^{6}$. Piliakalnis yra tokios nematerialios savybès naratyvinis ịkūnijimas fizikoje - jis yra pirmapradis visu miestu objektas, todèl atitinka Alexanderio „švento objekto“ apibūdinimą. Žvelgiant $\mathfrak{i}$ kupiną prieštaravimą Vilniaus miesto istorinę, urbanistinę ir ar- chitektūrinę raidą, matysime, kad ir dabar, nebūtinai dèl planuotų sprendimų, ar dar daugiau, nebūtinai dèl teisingu sprendimu, Vilnius yra laikomas vienu žaliausių Europos miestų. Tai yra naratyvinis pavyzdys, kaip veikia savireguliatyvus mechanizmas, turịs begalinę sąryšiu galimybę urbanistinëje karalijoje.

Tačiau esminis matafizikos ir paveldo architektūros principas, kalbant apie miestus, yra ne tas, kad yra „šventas“ objektas su genotipine potencija ir kad fenotipinè apykaita, vykstant kaitai, šiuo atveju yra tokia pat svarbi. Svarbiausia šio Alexanderio modulio pritaikymo paveldo metafiziniam supratimui prasmè atsiskleidžia per tai, jog kintant „šventos" vietos ar objekto aplinkai, būtent miesto aplinkoje, pradedant eopoliais ir baigiant megalopoliais, kinta ir pati šventosios vietos fizinè bei mentalinè, išorinè ir vidinè sandaros konfigūracija. Kiekvienas naujai pridètas pastatas, kiekviena naujai sukurta funkcija pakeičia „šventosios" fenotipini poveiki, o jo pradinis, inicijuojantis vietovę genotipas tampa paslėptas dažniausiai po įvairiais formaliais klausimais.

Tad ir miesto (urbanistikos ir architektūros) paveldo uždavinys šiuo požiūriu bus suvokiamas kaip nuolatinė monadologinè pastanga visu pirma atpažinti „šventajij objektą“, o ji atpažinus, nuolatos perkurti kituose objektuose laiko tèkmèje. Šiuo atveju miestas kaip begalinių inicijuojančio „šventojo“ objekto ryšiu su naratyvą tęsiančiais objektais darinys visada yra begalinis, o jo loginis apribojimas, sakykime, fizinio autentiškumo požiūriu, yra neribojamas, nes tokios vietos autentiškumas bus išreiškiamas $\infty$ (naratyviniu 
jungčių ir jų rezultatų) +1 . Tad miestiškas autentiškumas yra monadologinis ta prasme, jog vienis, kuris iš pradžių glūdi tik ,„̌ventajame objekte“", pasklinda ir nusidriekia į tęsiančiuosius naratyvą objektus. Todèl miestiškas sakralumas, kaip pažymi ir Denisas Crossgrove'as, visada apibrèžiamas per intuityvią kūrybos potenciją ${ }^{7}$, reiškiančia, jog sakralumas miestiškos aplinkos architektūroje randamas per poetinę gebą perkurti objektą kad šis išlaikytų savo prasmę.

M. Heideggeris tokio perkūrimo būtinybę grindžia ontologiškai. Vienas žymiausių naratyvo teorijos paveldui kūrejų Nigelas Walteris, remdamasis Heideggeriu, teigia, jog paveldo objekto kaip meno kūrinio vertinimas per estetini formalų aspektą yra žalingas, nes pastoviosios vertès "suteikimas" toki objektą padaro tik objektu ${ }^{8}$. Walteris cituoja Heideggerị: „,būti kūriniu, tai reiškia formuoti pasauli <...> šventovè savo būtyje čia, pirmiausia suteikia daiktams pavidalą bei žmonėms suteikia ju požiūrị i save pačius. Šis ryšys lieka atviras ir aktyvus tol, kol kūrinys yra kūrinys, t. y. tol, kol dievas nuo jo nepasitraukè ${ }^{\prime \prime 9}$.

Be jokios abejonès, nei Heideggeris, nei Walteris neskiria miesto architektūros paveldo ir ne miesto, kaip antai kaimo architektūros ar tokios architektūros, kurios nesupa kasdienis sociumo gyvenimas, t. y. architektūros be gyventojų. Vis dèlto paveldo objekto kaip meno kūrinio funkcija - formuoti pasauli suteikiant pavidalą daiktams ir žmonėms, be abejo, yra miestiškos kultūros aspektas, kadangi sociumas, formuodamas požiūrị i save ir šiuo aspektu suvokdamas daiktus, yra linkęs nuolat keistis ir savo kaitai iprasminti jis kuria diskursus - laikinas aplinkos suvokimo struktūras, kurios veikia kaip minètas tęstinis fenotipas siekiant paaiškinti „šventąją vietovę" ir jos genotipini pradą.

Todèl mieste iš principo nèra nieko medžiagiškai autentiško, kas būtų apibrèžiama kaip autentiška Venecijos chartijos postulatais ar reliatyvistiniais Nars dokumento kriterijais, kurie deklaruoja autentiškumo kaip tokio supratimo kintamumą. Iš tiesu, autentiškumas nekinta, net ir kintant fizinei miesto išraiškai, arba jis bent jau nekinta tol, kol hermeneutiškai įmanoma atpažinti „,̌̌ventajji objektą" tęstiniuose objektuose, tiesa, jis pasiskirsto tolygiai tarp visų nauju struktūrų ir tam tikru momentu, būtent kultūrai virstant civilizacija arba pereinant iš vieno būvio i kita, net ir inicijuojantis genotipas, ta Alexanderio "šventa vieta“, tampa lygiaverčiu visiems antriniams, tęsiantiems naratyvą objektams. Kadangi laiko ir erdvės vienovès kaip begalybės imperatyvo aspektu visas laikas ir visa erdvè yra absoliutūs, tai „šventu objektu“, priklausomai nuo diskurso, gali tapti ir objektas, kuris yra chronologiniame laike naujesnis už savo aplinkos objektus. Kita vertus, inicijuojanti metafizinè substancija ir jos esminis turinys nekinta, nors pasikeičia ją apgyvendinantis fizinis objektas.

Todèl miestas savaime yra tąsus. Spinozos metafizika pripažǐsta, jog yra viena beribè substancija kaip absoliutas begalybės požiūriu, o Leibnizas teigia, jog yra begalybe sukurtų substanciju, tad savotiškai autorius pereina prie dvieju lygių begalybės: dieviško kokybinio absoliuto ir jo kuriamų predestinacijų kie- 
kybiniams aspektams ${ }^{10}$. Tad miesto raida kultūrų ir civilizacijų kontinuume atspindi savotiškai predestinuotą begalybės tapsmą - monadologinę entelechiją ${ }^{11}$, kai „,̌̌ventos vietos / objekto“ krūvis sukuria ir lemia begalinès sekos kitu pro- cesų konfigūracijų raida, pats dalyvaudamas ir lemdamas juos iš vidaus, ir sukurdamas savireguliacijos veiksni urbanistinëje raidoje, taip suteikdamas jai dèsningumą, tačiau pats ištirpdamas naujose substancijose.

\section{LAIKO IR ERDVĖS VIENOVĖS PAJAUTA UNIVERSALIOJE VIETOJE}

Amerikos architektas Frankas Lloydas Wrightas savo veikalo Nykstantys miestai (Disapparing cities) izžangai pasirinko dialektinio santykio tarp klajokliu ir sėslių gyventojų išryškinimą siekdamas parodyti pagrindines žmoniją veikiančias jègas - kaitos ir pastovumo siekius. Anot autoriaus, klajoklis remiasi laisva dvasia, pasikliauja gamtos ritmais, kurie ji gelbsti ir pražudo. Tuo tarpu sèslusis žmogus, jo dievas yra fortifikacija ir gynyba. Anot Wrighto, miestai - tai būtent tokio asmenybès tipo įsigalëjimo žmonijoje rezultatas ${ }^{12}$. Kad ir kaip būtu paradoksalu, statiškų struktūrų kūrẻjas yra tas žmogus, kuris inicijuoja laikinumą ir kaita, o štai laisvai judantis klajoklis yra pastovumo adeptas.

Pats architektas savo teorinèje kūryboje siekè kuo darniau sulieti abu šiuos pradus, ir šio siekio rezultatas, mano supratimu, geriausiai matyti jo konceptualiame darbe Broadacre city ${ }^{13}$. Būtent šis konceptas, nors priskiriamas bendrajai modernizmo architektūroje bangai, vis dèlto kitaip, nei plačiai nuskambèjusi E. Howardo "miesto sodo“ koncepcija, siekia sujungti vertikalujji - miestišką ir horizontalụji - savotiškai valstietiškąklajoklišką erdvinius pradus. Maisto auginimo ir apsirūpinimo autarkija, plačios atviros erdvès, tačiau tuo pat metu ir pavienis, visiškai miestiškas dangoraiži primenantis verslo bokštas labiau primena ūkininko sodybą - verslovę, nei vien tik miestą ar vien tik kaimišką vietovę. F. L. Wrightas mane, jog XX a. pradžios miestas tapo savotišku bendrabučiu savo gyventojui, kuriame jis jaučiasi nuomininku, o ne visaverčiu šeimininku.

Todèl planiné struktūra - atviros erdvès paieška - tampa atsvara miestuose isivyravusiam antropologiškai sėsliam pradui kvestionuoti. Vèliau Alexanderis mūsu jau aptartoje Pattern Language deklaruos, kad žmogui tiesiog pagrindiniu poreikiu tampa miesto ir kaimo pradu susiliejimas ir kad moderniame mieste šie abu pradai turi būti kuo arčiau vienas kito $^{14}$. Svarbu pabrèžti ir tai, jog kaimas Alexanderiui ir buvo kaip žemès ūkio paskirties verslovè su visais agrokultūriniais ir kitais sociokultūriniais atributais, o ne siauriau suprantamas ir dabartineje gyvensenoje dominuojantis „, antrujų namu" (second home) paradoksas, besiremiantis tik formaliomis kaimiškomis savybèmis, šitaip kaimą niveliuojantis iki tipinio priemiesčio semantinès reikšmès.

Tiek Wrighto, tiek Alexanderio žmogus trokšta išsivaduoti iš vertikaliosios kultūros. Visų pirma reikia pažymèti, jis nori išsivaduoti iš pastovaus judejjimo. Miestas - tai ne šiaip funkcijų daugybè, 
pastatų kompiliatyvumas ir tankus socialinių santykių tinklas. Tai veikiau yra imanentinis, savireguliacijos principu veikiantis noras tęsti ir kurti funkcijų ivvairovę plečiantis tiek i kokybinę, tiek ir, beje, dažniausiai, ị kiekybinę dimensijas. Todèl miestas begalinès aibès požiūriu yra ne tik padalintas (šv. Augustino žodžiais galima pasakyti „išsibarstęs“ laike ir erdvèje), bet ir neapčiuopiamas. Net ir tas , „šventasis“ objektas, būdamas abstrakcija, galiausiai nebèra fizinis objektas (kaip ir Šventaragio slènio konfigūracija yra nebeatpažįstama fizinèje plotmèje), todèl bet kuris objektas, turįs savyje monadologine entelechija ta prasme, jog turi potencialo būti „šventu“ - pirmapradžiu ir inicijuojančiu objektu, tačiau tuo pat metu niekas nėra šventas ir kiekvienas iš objektų tèra tęstinis.

Šio aspekto empiriniu įrodymu galètų būti Kinijos Liaudies Respublikos naujujuc miestų plètros aspektai. Šios šalies mokslininkai dviejose atvejo studijose pažymejjo, jog ypač kalbant apie sparčiai augančius provincijos miestus matyti paradoksas, kad juose vyrauja visiškai globalios formos architektūra, tačiau nepaisant jos unifikuotos konfigūracijos, detalèse išlieka aplinkiniams kaimams būdinga kokybinè erdvès supratimo sistema. Kalbant apie Honkonga, matyt, kosmopolitiškiausią ne tik Kinijos, bet veikiausiai ir viso pasaulio miestą identitetų ivvairovès (ar jo neapčiuopiamumo, nebuvimo) požiūriu, taip pat pažymėtinas panašus dalykas. $\mathrm{Na}$ Xingo ir kolegu atliktame nuodugniame urbanistinès erdvès tapatumo tyrime nustatyta, jog globali architektūra ir urbanistika vis tiek atspindi tradicines ki- niškas urbanistines struktūras ${ }^{15}$. Autoriai pabrèžia, kad toks įvykis veikiau atsitiktinis (savireguliatyvus, nes kyla iš hipotetinio "švento objekto". - K. R.) nei metodiškai suplanuotas. Anot autorių, visiškai nauja gatvių struktūra visai netikètai igijo savotišką tradicinės Kinijos kultūrai būdingą gatvių tinklą, primenanti tradicinio Kinijos miesto turgaus morfofaktūra, jis telkdavosi, priešingai nei Vakaru Europoje, ne koncentruotoje aikštëje, bet savotiškai tįstančiame aikštès ir gatvès hibridiniame modelyje. Galima teigti, kad šis „,neplanuotas atsitiktinumas" yra tam tikro mitologizuoto naratyvo apraiškos forma, kuri nulemta ne vieno autoriaus ar bendrojo plano autoriaus kūrybiškumo, bet autentiškos gyventoju kolektyvinès patirties ir sugebejjimo išsaugoti esmini paveldo turini visiškai nauja forma.

Tačiau šio empirinio pavyzdžio akcentas paveldo supratimo begalinès aibės aspektu yra tas, kad ir ",autentiškas“", išlikęs senas, tradicinis turgus viename ar kitame staigiai sprogusiame Kinijos megapolyje, jau nebeturi tos inicijuojančios vertès, kadangi abstrakti ji pagrindžianti nematerialioji substancija dabar jau nebepriklauso tik senam turgui, bet senas turgus yra priverstas ja dalintis su naujais globaliais kompleksais, kurie savireguliatyviai igyja senojo turgaus kokybinius bruožus laike ir erdvejje - urbanistineje formoje.

Tad bet kuri urbanistinè vieta - pastatas, erdvè tarp pastatų - ar santykis dèl imanentinio judejjimo poreikio niveliuoja prieš tai buvusio materialaus paveldo autentiškuma, jo dali persikeldama sau. Tokiu būdu bet kuri vieta yra visiškai 
tokia pat, loginiu požiūriu hierarchiškai negali stovèti aukščiau už kitą vietą, nes jos visos priklauso integraliai monadologinei sistemai, kaip tikejjo Spinoza, savotiškam vieniui. Šiame miestiškame vienyje kiekviena vieta yra skirtinga ir tuo pačiu metu tokia pati, nes joje žmogus patiria tik negrynos, išskaidytos begalybès aspektą ${ }^{16}$.

Tačiau ar yra tokiu vietu ir tokios architektūros, kuri pasižymi išgrynintomis ir universaliomis savybėmis begalinès aibės aspektu. Leibnizas, kaip interpretuoja Slowikas, pateikia universalios vietos apibrèžima, koreliuojantį su I. Newtono absoliučios vietos substancijos kategorija. Anot jo, tai vieta, kurioje išreikšta visiškai viskas, kas būdinga bet kuriai potencialiai erdvei bet kuriuo duotuoju laiku ${ }^{17}$. Tad tai vieta, i kurią sutraukiama visa įmanoma monadologinè substancija ir tokia būsena laike, kai mūsų ịvardyta „šventa vieta / objektas“ visiškai susilieja su savo abstrakcija nematerialiaja substancija ir todèl nebeprivalo kisti. Tokiam reiškiniui izvykti reikia tam tikro santykio tarp subjekto ir objekto, nes, kaip teigia Gregoras Riminietis, begalybės pajauta egzistuoja kaip abstrakcija mentaliniame lygmenyje, būtent subjekto, mąstančio begalybę, sąmonèje ir todèl yra metafiziška, nes fizinëje tikrovëje neegzistuoja. To santykio pagrindinis sandas yra savotiškas, Mokytojo Eckharto žodžiais tariant „,atsižadèjimas savęs": "tad jei kiekvienas žmogus nori būti panašus ị Dievą (nes kiekvienas kūrinys gali tapti panašus i dievą), toks jis gali tapti tik per atsižadèjimą. Atsižadèjimas veda žmogu i tyruma, nuo jo i paprastuma, o nuo pastarojo - i pasto- vumą. Būtent šios savybės daro žmogu panašų i Dievą ${ }^{\prime 18}$. Šiuo atveju kalbama apie minètą pirminę monadologinę begalinès aibės esmę, kuri atsiveria kaip skirtis tarp Leibnizo ir Spinozos begalybès sampratų. Todèl atsižadejimas čia vyksta nuo urbanistinio noro keisti esamas ir kurti naujas funkcijas, nuo to Aldo Rossi išreikšto miesto tapatumo imperatyvo - judejjimo.

Tad santykis tarp subjekto ir objekto, potencialiai formuojantis universalios ar / ir absoliučios vietos galimybę, turi būti nesuinteresuotas atlikti kokią nors pasaulietinę, utilitarią funkciją todèl toks objektas turi būti ne urbanistinis, o pats sau - išimtas iš kultūrinio erdvinio konteksto. Kitaip tariant, „šventas objektas“ be pridètinès potencijos kurti begalinę ryšiu ir prasmių aibę yra įmanomas tik tuo atveju, Alexanderio žodžiais tariant, jei aplink ji nebus formuojama aplinka, besistengianti perimti ir mainyti, tačiau išlaikant pagrindinius principus, atspindèti „„̌vvento“, inicijuojančio objekto nematerialiosios substancijos turinį.

Todèl tas objektas yra perkeliamas už miesto, erdvès, kurioje karaliauja sociumui būtinas kaitos imperatyvas. Ir nors kaita (urbanistinè) daugeliu atveju vis tiek yra predestinuota tos nematerialios substancijos, kuriančios inicijuojanti „šventą objektą", vis dèlto joje (kaitoje) yra sukuriamas autentiškos patirties negalimumo paradoksas. Alexanderis savo trumpoje diskusijoje apie miesto struktūrą lemiančiu ryšių konfigūraciją teigè, jog mieste viskas yra kintama ir net pats pastoviausias darinys visada kinta, glūdinasi nuo didelio miestiečiu socialinio srauto ir juo išreiškiamo veiksmo ${ }^{19}$. Todèl 
nėra dviejų vienodų elementų skirtingose laiko vienetuose.

Wrightas siūlo eliminuoti kultūrinị konteksta, kiekvienam kultūriniam vienetui (kad ir urbanistinejje erdvëje) sukuriant, kiek įmanoma, natūrinį kontekstą ir šitaip miestą grąžinant i i eopolio pakopą. Šis konceptas nèra naujas ar autentiškas idejos originalumo požiūriu. Veikiau priešingai - tai savotiškas predestinacinis imperatyvas visų laikų tautoms ir kultūroms - išskirti tam tikrus objektus iš savo tradicinès kultūrinès aplinkos šitaip suteikiant jiems „šventumo“. Tad civilizacijos, grindžiančios savo egzistavimą objektyviais ir apskaičiuojamais objektais, kūrè pirmuosius priemiesčius (villa suburbana fenomenas Renesanso laikų Italijoje), barokiškus sodus įrèminančius dvarus, tarsi siekiant sugrižti, kad ir i simuliuota, bet tam tikrą vieni, kur visi esantys (buvę ir būsiantys) daiktai atsiranda viename daikte. O mitine struktūra gristos civilizacijos stato ištisus miestus nekropolius ar šventus akropolius, nors juose žmogus arba nebūna, arba bent jau negyvena. Būtent objekto eliminavimas nuo masinės subjektų itakos (ju noro kurti ir nuolatos keisti objekta, galime prisiminti Heideggeri) yra vienintelis būdas suteikti objektui tą kontempliatyvų santyki tarp subjekto ir objekto.

Kita vertus, toks objektas, jei jis egzistuoja, yra įmanomas arba primityvios kultūros pradžioje, arba įsigalèjus civilizacinèms normoms visuomenèje. Pirmapradis, inicijuojantis ar „šventas" objektas pirmiausia yra tuščias savo fizinès struktūros sudètingumo aspektu. Billas Hillieras tokiems pirmapradžiams ti- pams priskiria Amerikos indènu palapines ar iki šiol naudojamas mongolu jur$\operatorname{tas}^{20}$. Būtent pastarają erdvinę struktūrą autorius, remdamasis antropologiniais stebejjimais, vadina pirmine mikrovisata, nes mongolui jurta yra visas pasaulis, netgi struktūriškai nedalomas jokiomis vidinemis pertvaromis ir erdvèmis, o gyvenamojo ploto paskirstymas (vyro ar moters pusè) yra suvokiamas savaime, remiantis griežta tradicijos taisykle. Tad mongolai, besinaudojantys jurtomis ir keliaujantys paskui gyvulių bandas, visada yra savo kultūros priešaušryje, ji integruoti į konservatyvų sėslų pilietị ir nori Wrightas.

Tačiau kitaip nei teigia Hillieras, mongolo jurta nėra begalinès aibès materializacija architektūroje ne todèl, jog jurta turi sąryši su kitomis jurtomis ir yra veikiama socialinių santykių. Taip yra todèl, jog pati jurta kyla iš savęs ir nieko neperkuria, joje juntamas trūkumas tos kūrybinès nematerialiosios substancijos, kuri kurtų kitus turinius, kitas funkcijas ir kitokius objektus bei suteiktú pamatą egzistencijai laike ir erdvèje. Kita vertus, platesniu požiūriu mongolo jurta yra vienas tų pirmųjų erdvės suformavimo genotipu, kuris vis tiek nurodo galutini raidos tikslą - gyvenimą visiškoje harmonijoje su visa izmanoma fizine ir metafizine aplinka. Vis dèlto mongolui tai pradžios taškas, kuris to tikslo link pasislinkęs nèra nei per erdvės ar laiko dalelę, nors ir pats hermeneutiškai laikytinas eschatologiniu tikslu.

Iliustruodami pradžios ir pabaigos vienovę kaip didžiausią i̇manomą begalinès aibès architektūrinèje erdvèje poty- 
rio supratima, galime pateikti empirini pavyzdį iš kultūrinès antropologijos tyrimų apibendrinimo, kuri pateikia Markas Suttonas. Autorius teigia, jog antropologiškai užfiksuota daugybė atvejų, kai medžiotojų-rankiotoju bendruomenès, vèliau virtusios sėsliomis žemdirbių kultūromis, igydavo sudètingą socialinę, ekonominę ir kultūrinę gyvenimo organizavimo struktūra, savo pobūdžiu artėdavusią prie savotiškos civilizacijos būvio, staiga imdavo ir griždavo prie visiškai sėslaus klajokliško gyvenimo ${ }^{21}$. İdomu ir tai, jog toks grižimas nebuvo nulemtas kitu genčiu ar bendruomeniu karinio, ekonominio ar panašaus spaudimo, o vienintelis galimas paaiškinimas yra požiūrio i̇ tai bendruomenei priimtiną pasaulio sandarą neatitikimas sudètingos, biurokratejančios gyvensenos, kuri tolsta nuo esmès supratimo. Toks grižimas tas bendruomenes vesdavo prie visiško išnykimo - taigi i pradžiu pradžios būklę.

\section{KAIP ATRODO „UNIVERSALUS" ARCHITEKTÜROS PAVELDO OBJEKTAS}

İdomu tai, jog Marcas Auge'as savo studijoje, skirtoje "ne vietoms“", tai yra tokioms tranzito erdvèms, kuriose juntamas visiškas tapatumo ir pastovumo stygius, kaip „ne vietas“ apibūdino dideles automobilių stovejjimo aikšteles šalia prekybos centrų, oro uostus, viešbučio kambarius ar greitkelius. Tai vietos, kur žmonès negyvena, kur nevyksta glaudūs socialiniai santykiai, bet vis dèlto čia vyksta didžiausia įmanoma kaita ir yra daugiausia dinamikos ${ }^{22}$. I "ne vietas" autorius žvelgia kaip šiuolaikinis etnologas - jų nei kritikuoja, nei gina, tačiau vertinant veikala, galima daryti išvada, jog kuo didesnis judejjimas ir tinklaveikla, besiremianti kvazianonimiškumo siekiu, tuo mažiau vieta yra ta vieta, kuri potencialiai galètų bent jau tęsti tos „švventos vietos“ inicijuotą judèjima, kurio fenotipinè struktūra vis tiek primintų tos ,šventos vietos“ nematerialaus dèmens esmę.

Israelis Korenas (2011) apibrèžè pasaulio sandaros laike ir erdvëje modeli:
Evoliucija - tai dviejų, nuolat konfrontuojančių jègų mūšio laukas: viena jèga - tai progreso jèga, o antroji - jejga, verčianti subjektą grižti atgal prie savo šaknų (regreso, pasipriešinimo pokyčiams jèga. K. R.). Progreso ir vystymosi jèga yra ta, kurią naudojant buvo sukurtas esamas pasaulis, bet tam tikrais momentais šita jèga atstumia tą pasaulio vaizdini, kuris davė kūrybinę energiją esamosios situacijos susiformavimui, - taigi net ir kiekvieną kartą naujai sukuriamas pasaulis vien dèl progreso jègos yra vedamas i pražūtį. Regreso ar grị̌imo / pasipriešinimo jèga yra ta, kuri, reaguodama i progresa, saugo žmoniją nuo visiško paklydimo laike ir verčia prisiminti tą kūrybinès energijos šaltini, kuris suponavo esamosios situacijos susidarymą. Kad ir kaip būtų, individas nuolatos renkasi tarp šių jẻgu. ${ }^{23}$

Žvelgiant futurologiškai, ateityje žmonija vèl turès taikytis prie eopolio ir polio struktūra paremtos urbanistinès struktūros, nes megapolinis ir megalopolinis gyvenimo būdas eliminuos bet kokị tapatybès komponentą ir „šventas objektas" taps vis sunkiau atpažistamas, taigi 
ir sunkiau suvokiamas taps egzistencijos pagristumas. Tačiau kuo spartesnis ir niveliuojantis ,„šventą vietą" progresas, tuo didesnè tampa pasipriešinimo jẻga, dar labiau išryškinanti tos „šventos vietos" bruožus fiziniame kontekste. Galiausiai, augant ekonomikai ir vystantis technologijoms, tikriausiai esminiu klausimu taps ne gerovès tobulinimas, bet dvasiniai gyvenimo prasmès klausimai.

Antroje dalyje apibrezžta universalios vietos arba baigtinès šventos vietos struktūra - vieta, kuri prasideda ir baigiasi savyje, tuo pat metu viename laiko ir erdvès taške atspindinti visą žmonijos raidos procesa, - taip pat suponuoja tam tikrą socialinių ryšių atsisakymo imperatyvą siekiant sustiprinti santyki tarp subjekto ir objekto, taip suteikiant jiems abiem transcendentini turini, kuris potencialiai igalina begalybės suvokimą ar priartejimą prie jo.

Kakudzo Okakura savo garsiajame veikale Arbatos knyga (The Book of Tea) idomiai paaiškino šintoizmo ir budizmo tradicijų paveiktą japonišką pasaulio sandaros samprata, kurioje arbatos gèrimo ceremonija savo metafizine prasme apima visą Visatos egzistavimo esmę nuo pradžiu pradžios iki visiškos pabaigos $^{24}$. Tai tarsi savotiška tobulumo kompresija, savotiška begalybè, suvokta per baigtini laiko tarpą. Tas pats Okakura pabrěžè, jog toks tobulumo siekis kasdienybeje, taigi urbanistiniuose santykiuose, ekonomikoje, politikoje ne tik kad nebūtinas, bet ir nepageidaujamas dèl to, kad jis stabdo judejimą. Todèl žmogiškasis, kasdienis, žmogaus veiklos konfigūracijos tobulumas yra išreiškiamas per trūkumą - Heideggerio žodžiais tariant, noch nicht jetzt būsenoje ir šio nulemtą materijos kaitą siekiant ištaisyti trūkumą.

Tad universalios architektūros potencialą turi tos vietos ir objektai, kurie yra atviroje erdvëje ir nèra niekaip susiję su utilitarumu ar kokia kita socialine ekonomine funkcija, kaip antai ipaminklinimas, įamžinimas, vietos įvaizdžio formavimas ir t. t. Jų egzistavimo priežastis turi būti apibrèžiama per atsitiktinumą ar savotišką loginę prieštarą kasdienybės pasauliui. Vienas idomiausiu tokias savybes turinčiu pasaulyje pripažistamu objektu - brolio Klauso koplyčia, suprojektuota garsaus architekto Peterio Zumthoro ir pastatyta tiesiog viduryje dirbamo lauko. Panašus, bet kur kas mažiau žinomas pavyzdys - Paežerio Švč. Trejybės koplyčia šalia Nemakščiu miestelio Raseinių rajone. Abieju koplyčiu atsiradimas prieštarauja bet kokiai socialinei logikai - yra gristas intuicija ir atsitiktinumu. Švč. Trejybẻs koplyčia į lauką šalia Nemakščiu buvo perkelta sudegus čia stovejusiai bažnyčiai ${ }^{25}$. Abu objektai taip pat pasižymi savotiška architektūra, kuri apima dichotominius pradus: iracionalumas ir racionalumas, abiem būdingas intuityviai pajaustas santykis tarp simetrijos ir asimetrijos. Verta paminèti Agilių koplytėlę Šiaulių rajone, taip pat daugelis etninių mediniu Žemaitijos bažnyčių ir koplyčiu turi universaliai architektūrai būdingu savybių, atspindinčiu lietuvišką gamtos ir kultūros dermę.

Tokie objektai, išimti iš kasdienio konteksto, sutraukia laiką ir erdvę aplink save ta prasme, jog nei ju fizinis autentiškumas kinta dèl aplinkos pokyčio (nes aplinka čia tiesiog nekinta ir neturi buvusios, esamos ar būsimos kaitos ženklų), nei yra atspindintys begalybę dèl 
potencialo užbaigti monadą (kai begalinė aibè prasideda ir baigiasi savyje).

Tiek Brolio koplyčia, tiek ir Švč. Trejybès koplyčia iš esmès apibrèžia visą urbanistinę - architektūrinę erdvę ta prasme, jog būdamos asketiškos, iprasmina visą žmonijos siekí minimizuoti architektūrinę formą. Tačiau kadangi jų asketiškumas netobulas, neišbaigtas ir remiasi plastika, tai jos, tuo pat metu visiškai neprarasdamos šios „,atsižadèjimo" savybės, suponuoja ir pagrindžia visus teatrališkus objektus, kurie buvo, yra ir bus kuriami istorijos kontinuume. Tad atmetus begalinès kaitos pajautos sieki fizinèje erdveje ir ją suvokiant paprasčiausiai mąstyme kaip abstrakcija, mes, žiūrèdami i tokius objektus, visada išpildysime Mokytojo Eckharto priesaką: „Viename gerame būde reikia įžvelgti visus gerus būdus, bet ne šio būdo ypatingumą. ${ }^{“ 26}$ Todèl transcendentinis šiu objektu, jei jie egzistuoja, pajautos būdas lemia tai, jog galbūt patyrę vieną universalu ar absoliutu objekta, mes galime suprasti visas šias vietas integraliai be poreikio apmąstyti jų fizinę išraišką, bet veikiau suvokiant ju egzistavimo priežastis - būtent kultūrini savo krašto tapatumą.

\section{IŠVADOS}

Siekiant giliau pažvelgti i žmogaus kuriamą kultūrinę aplinka, buvo pasirinktas begalybès ir absoliuto suvokimo, jei jis įmanomas, atspirties taškas. Matyti, jog urbanistinè aplinka yra begaliniu jungčiu integralus tinklas, kai viena detalè gali suponuoti daugybę funkcijų potencialioje ateityje. Ir atvirkščiai, judèjimo kaip tokio atsisakymas, pastovumo siekis suponuoja ne jungčiu nutrūkimą, bet veikiau ju priežasties supratimą. Apskritai begalinės vyksmų aibès supratimas yra subjektyvus tuo požiūriu, kad vyksta mąstymo lygmenyje, bet vis dèlto jis kuriamas ir fizineje realybeje - kada žmogus nuolatos bando, nors ir netiesiogiai, išsivaduoti iš supančio sociumo ir visą sau reikalingą aplinką sutelkti ì vieną erdvę. Tai yra aptartieji priemiesčiu ar vilu pavyzdžiai. Tačiau kadangi toks būdas yra funkcinis, utilitarus, jis niekada nebūna visiškai grynas.
Kitas kertinis aspektas yra tas, jog fizinio paveldo metafizinè reikšmė yra irankis suvokti ir pačius daugiau praktinius vietos veiklos poreikius. Vietovès mitas ir inicijuojanti „,šventa vieta“" visada bus atsakymas i bet koki praktini sprendimą, nes ji yra savotiškai įrašyta i miesto ar vietos genetini kodą ir pasireiškia metaistoriškai, nepriklausomai nuo žmonių intencijos. Galima teigti, jog savireguliacija veikia kaip intuicija, kurią formuoja nuolatinis kontekstas.

„Šventos vietos“ ir absoliuti / universali architektūra yra įmanoma, kaip minèta, abstrakčiame mąstyme ir atskirta nuo judèjimo konteksto. Tai tokia būsena, kai objektas tiek fiziniu, tiek ir funkciniu atžvilgiu redukuojamas iki nieko kasdienybės poreikio žmogui prasme. Tik eliminavus funkciją logika, priežasti, materijos konteksta imanoma tokia patirtis. 


\section{Literatūra ir nuorodos}

${ }^{1}$ Eric Steinhart, A mathematical Model of Divine Infinity, Theology and Science 7(3), 2009, p. 261-274.

2 S. G. Ventakaramani, The Magnificiet Convergence: Science, Metaphysics and Religion. America Star Books, 2015.

${ }^{3}$ Kastytis Rudokas, Naratyviné miesto urbanistikos ir architektūros paveldo samprata. Daktaro disertacija. Kauno technologijos universitetas, 2017.

${ }^{4}$ Christopher Alexander, et al., The Pattern Language. Oxford University Press, New York, 1977.

5 Tomas Kačerauskas, Kultūros tradicija ir naujybè. Prieštaros ir sąveikos, Logos 63, 2010, p. 145-156.

6 Vincas Vyčinas, Raštai. Vilnius: Aidai, 2009.

7 Dennis Cosgrove, Should We Take it All so Seriuosly? Culture, Conservation and Meaning in the Contemporary World, Durability and Change. The Science, Responsibility and Cost of Sustaining Cultural Heritage. D. E. Cosgrove, W. E. Krumbein, P. Brimblecombe \& S. Staniforth (sud.). New York: John Wiley, 1994, p. 259-266.

8 Jam, be jokios abejonès, šiuolaikinè postmoderni visuomenè skuba atributuoti įvairias subjektyvistines vertes.

${ }^{9}$ Nigel Walter, From values to narrative: a new foundation for the conservation of historic buildings, International Journal of Heritage Studies 20 (6), 2015, p. 634-650.

10 Ohad Nachtomy, A Tale of Two Thinkers, One Meeting, and Three Degrees of Infinity: Leibniz and Spinoza (1675-8), British Journal for the History of Philosophy 19 (5), 2011, p. 935-961.

11 Ohad Nachtomy, Monads at the bottom, monads at the top, monads all over, British Journal for the History of Philosophy 26 (1), 2018, p. 197-207. Cit. iš Michel Fichant, „L'invention métaphy- sique. An introduction to G. W. Leibniz, Discours de métaphysique suivi de Monadologie et autres textes". Paris, 2004, p. 130.

12 Fran Lloyd Wright, Disapparing City. New York, Stantford press, 1932.

13 Idëja detalizuota būtent veikale Nykstantys miestai.

14 Alexander, Pattern Language.

15 Xing Na, Historic definition of Public Space: Inspiration for High Quality Public Space, The International Journal of thr Humanities 7 (4), 2010, p. 39-56.

16 Edward Slowik, The Deep metaphysics of space. An alternative history and ontology beyond substantivalism and relationism. Springer International Publishing, 2016.

17 Ten pat.

18 Johannes Eckhartas, Traktatai ir pamokslai. Vilnius: Aidai, 1998, p. 148.

19 Christopher Alexander, City is not a tree, Architectural Forum 122 (1), 1965, p. 58-62.

20 Bill Hillier ir Juliene Hanson, The Social Logic of Space. Cambridge University Press, 2005.

${ }^{21}$ Mark Q Sutton ir E. N. Anderson, Introduction to Cultural Ecology. New York, Altamira Press, 2010.

22 Marc Augé, Non-Places: An Introduction to Anthropology of Supermodernity. Verso, 1992.

${ }^{23}$ Israel Koren, "Main issues in Friedrich Weinreib philoshophy". Daktaro disertacijos santrumpa. The Hebrew University, 1996. Prieiga per internetą: <http: // jec2.chez.com / resumkoren1.htm >

${ }^{24}$ Kakuzo Okakura, The Book of Tea. Tuttle Publishing, 1906.

25 Žr. < http://www.autc.lt/lt/architekturos-objekt ai/1417? rt=3\&type $=2 \& s s=$ raseini $>$

${ }^{26}$ Eckhartas, Traktatai ir pamokslai, p. 56. 